\title{
The Role of Islamic Boarding School as Center of Excellence in Sheep Farming Development, Ngawonggo Village, Tajinan, Malang District, Indonesia
}

\author{
Ardhitacahyaghani Aulia Arsya ${ }^{1 *}$, Siti Azizah ${ }^{2}$ \\ and Umi Wisaptiningsih Suwandi ${ }^{3}$
}

\author{
${ }^{1}$ Student of Magister Program, Socio-economics Department, Faculty of Animal Science \\ Brawijaya University, Malang, Indonesia
}

${ }^{2}$ Lecture of Magister Program, Socio-economics, Department, Faculty of Animal Science Brawijaya University, Malang, Indonesia

${ }^{3}$ Lecture of Magister Program, Socio-economics Department, Faculty of Animal Science Brawijaya University, Malang, Indonesia

E-mail: ardhitacahyaghani@gmail.com; siti.azizah@ub.ac.id; uningsih56@ub.ac.id

\author{
*Corresponding author details: Ardhitacahyaghani Aulia Arsya; \\ ardhitacahyaghani@gmail.com
}

\begin{abstract}
The research was carried out from November to December 2020 in Ngawonggo Tajinan Village, Malang Regency. This study aims to explain the role of Islamic boarding school as center of excellence in the development of sheep farming in Ngawonggo Village, Malang Regency. The method used in this research is qualitative research with descriptive data analysis. The result of this research is the role of the Angkring Fathul Ulum Islamic boarding school as a center of excellence in the development of sheep farming, namely: it is as an educational center; students have a better understanding of religion than before; students can practice religious knowledge in people's lives, especially those in Ngawonggo Tajinan Village, Malang Regency by educating them to have good morals; religious centers can increase knowledge about religion and carry out routine recitation activities, including community development centers. The action taken by an Islamic boarding school helps in making people aware of the problems they are experiencing so that the awareness process can lead to the empowerment of the community towards social welfare.
\end{abstract}

Keywords: traditional Islamic boarding school; center of excellence; sheep farming; social welfare; Indonesia

\section{INTRODUCTION}

The development of sheep farming in Ngawonggo Tajinan Village, Malang Regency is one of the programs in the National Medium-Term Development Plan (RPJM). The development in the village was carried out because the village is suitable to be used as a center for sheep by utilizing available resources such as land and forage which is quite a lot and adequate, to meet the economic needs of the community and the motivation of the community is high enough for sheep farming development.

Islamic boarding schools as Islamic religious education institutions situated and developed in Indonesia, have given an impression and made influence on the formation of character and the spread of Islam in remote parts of the country. In addition to providing religious and general education, Islamic boarding schools also participate directly in community activities, participate in providing counseling on environmental health issues, agriculture especially giving lectures (da'wah) in mosques, recitations, taklim assemblies, livestock business and so on.
Therefore, it must also be a feature of the lives of the students to be able to understand and appreciate the aspects of community development.

Islamic boarding school as a place of religious education has a clear social base, because its existence is integrated with the community. In general, Islamic boarding school live from, by, and for the community. This vision demands that the role and function of

Islamic boarding school be in line with the situation and condition of the society, nation and state that continues to develop. Meanwhile, as a community, Islamic boarding school can play a role as a driving force for efforts to improve community welfare considering that Islamic boarding school is a social force that is quite large in number (Assa, 2007). This research was conducted because it is necessary and to describe how the role of Islamic boarding schools as a center of excellence for Angkring Fathul Ulum towards the development of sheep farming in Ngawonggo Tajinan Village, Malang Regency. 
The Traditional Islamic Boarding School Sheep Husbandry Program in Tajinan Village, Malang Regency, started in 2018 to empower Islamic boarding school students and sheep breeders. The long-term program objective is to empower the economic welfare of rural communities (Azizah, 2020).

The role played by an institution or organization is an affirmation of the functioning of the institution to individuals and groups in the surrounding environment. Like the existence of a boarding school in a place, it will make an important contribution to the surrounding community. This contribution is a manifestation of good management cooperation between the Islamic Boarding School and the community. So that the role of Islamic Boarding School can be an agent of change for life in many ways such as religious, economic and other values.

\section{STUDY AREA}

Ngawonggo Village is included in the Tajinan District, Malang Regency with an area of 375,628 Ha. Plain with an average elevation of $700-800 \mathrm{~m}$ above sea level. Administratively, the Village area is located at the southern end of the Tajinan District which is directly adjacent to Wajak District with the following boundaries: North side: Purwosekar Village, Tajinan District to the East: Ngembal Village, Wajak District South side: Kidangbang Village, Wajak District West side: Pandanmulyo Village, Tajinan District

The distance from Ngawonggo Village to the sub-district capital is $4 \mathrm{~km}$, which can be reached in about 15 minutes. While the distance to the district capital is $20 \mathrm{~km}$, which can be reached in about 0.7 hours.

Visually, the administrative area of Ngawonggo Village can be seen in Figure 1.

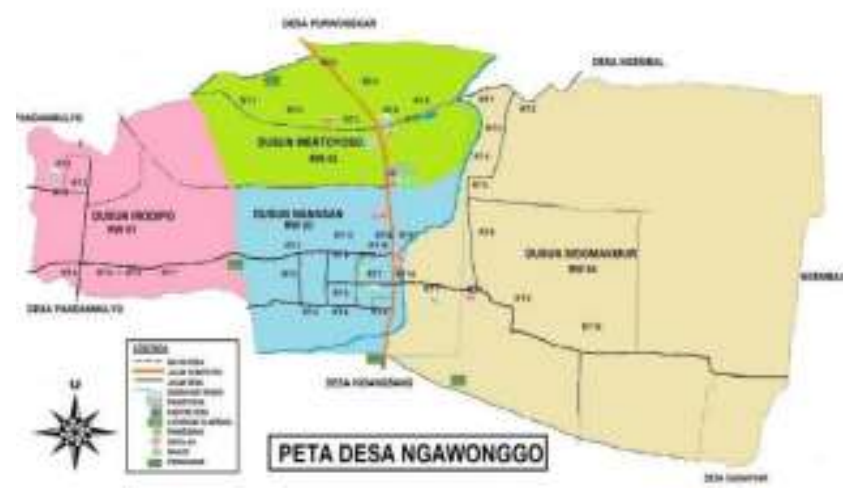

FIGURE 1: Ngawonggo Village Map

Angkring Fathul Ulum Islamic Boarding School is one of the educational institutions engaged in the religious and general fields, which aims to form a generation that is Islamic, has good morals and has quality in various ways so that it is able to keep up with current and future technological advances. According to Azizah et al., (2020) stated that the Angkring Fathul Ulum Islamic Boarding School which was pioneered in 2015 and was only officially registered based on the diploma of the Angkring Fathul Ulum Islamic Boarding School Foundation (officially recorded in the Notary Establishment Deed No: 10 issued on 21 October 2019 and has been registered with the Ministry of Law, Islamic boarding school is one of the potential institutions in Ngawonggo Village. Through its leader named Ustadz Habib, Islamic boarding school invites the surrounding community and students to build their villages.
Angkring Fathul Ulum Islamic Boarding School in Tajinan District, Malang Regency. The general pattern of learning at the Angkring Fathul Ulum Islamic boarding school is the standard competencies set in each field of Islamic religion, general science, skills, social and da'wah, skills activities and community economic development.

Activities related to the field of economic development through the development of sheep farming business, are intended so that the Angkring Fathul Ulum Islamic Boarding School has activities that can support the operational activities of the Islamic boarding school itself. The activities held are cooperatives, businesses in the field of agribusiness (agriculture), businesses in the livestock sector. As for activities related to empowering the surrounding community, in terms of human resources,

The Angkring Fathul Ulum Islamic Boarding School collaborates with local farmers and breeders in seeking agricultural products and developing optimal sheep farming businesses and providing satisfactory income.

\section{SHEEP FARMING PROGRAM IN TRADITIONAL ISLAMIC BOARDING}

The development of a sheep business in Ngawonggo Village, Malang Regency is one of the programs in the National Medium-Term Development Plan (RPJM). The development in the village is carried out because the village is suitable to be a center for sheep livestock by utilizing available resources such as sufficient and adequate land and forage, to meet the economic needs of the community as well as high community motivation for sheep development efforts. The plan to develop a sheep business in Ngawonggo Tajinan Village, Malang Regency has been carried out for 3 years. First started in 2018, namely making planning or initial planning in the form of providing knowledge to the community regarding the development of the sheep business then in 2019 starting to make preparations, providing counseling and providing education related to animal husbandry.

The development of sheep farming in Ngawonggo Village is also carried out to promote the name of the Islamic boarding school with the desire of the community to raise sheep from the community and breeders as well as the solidarity of the community in the village. Islamic Boarding School with a spirit of development are concrete examples of Islamic Boarding School efforts that not only concentrate on developing Islamic knowledge, but they are also institutions that care about the economic conditions of the surrounding community who generally work in the informal sector, such as small entrepreneurs, traders, breeders and farmers.

The development of sheep farming in Ngawonggo Tajinan Village, Malang Regency uses thin-tailed sheep with a total of 40 sheep with 27 adults and 13 chicks. According to Dewi, U.S et al., (2014) stated that sheep are small livestock that have many benefits and uses, one of which is producing meat that can meet the needs of animal protein for the community. The existence of this sheep is a business capital for breeders who cultivate, so that the existence of sheep can not only create jobs and business fields, but can also provide income for the perpetrators.

According to Febrianno and Siahaan (2012), livestock activities, especially sheep farming, are expected to overcome the lack of technological capital from the Ngawonggo Village community. Because livestock has been done for years in the community, it is not done professionally. Sheep are considered worthy because they have almost the same characteristics as goats bred so far. In addition, sheep also have several advantages over goats. 
Sheep are preferred over goats because of several characteristics that sheep have, namely:

1) Sheep adapt easily to new environments

2) Sheep live in groups so they are easily accessible for grazing

3) Sheep breed fast

4) Sheep are more resistant to disease

5) Lamb meat is more tender and doesn't smell like goat meat

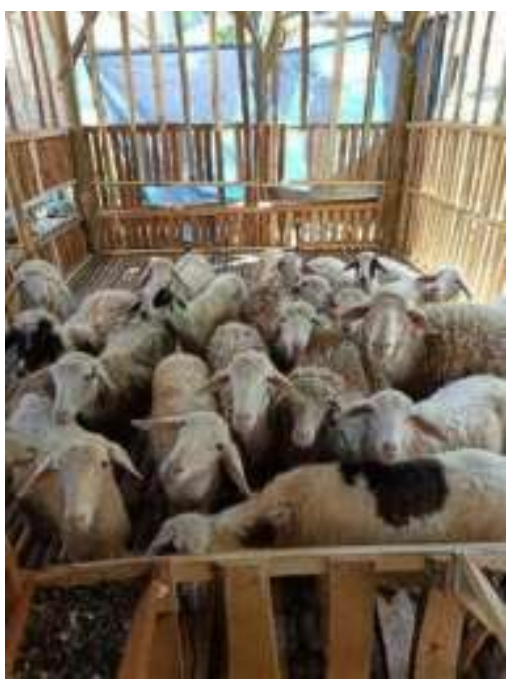

FIGURE 2: Sheep farming in Ngawonggo Village

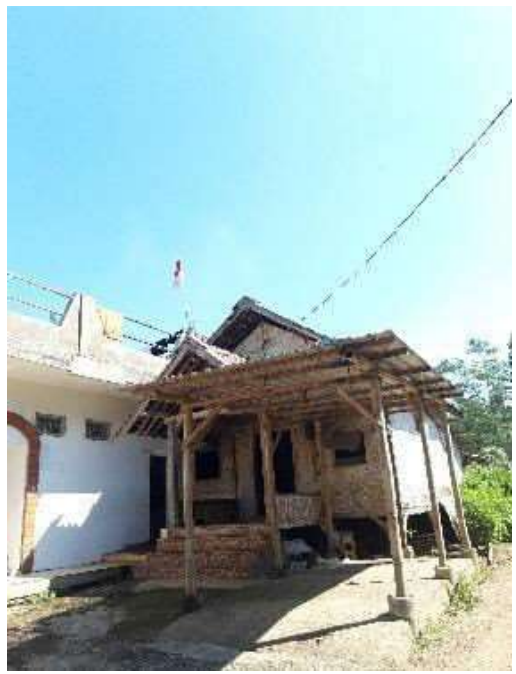

FIGURE 3: Angkring Fathul Ulum Islamic Boarding School

\section{THE ROLE OF ISLAMIC BOARDING SCHOOL AS CENTER OF EXCELLENCE}

Islamic boarding schools are Islamic educational institutions to study, understand, explore, appreciate, and practice Islamic teachings by emphasizing the importance of religious morals as guidelines for daily behavior. Subsequent developments, Islamic boarding schools not only act as educational, religious, and social institutions but also play a role in community development.

Islamic boarding school as a center of excellence not only acts as a place for the transfer of religious knowledge but also general knowledge. So that the Angkring Fathul Ulum Islamic boarding school seeks to add various educational models. The Angkring Fathul Ulum Islamic Boarding School developed a learning method that is often referred to as a diniyah study. According to Azizah et al., (2020) stated that the Angkring Fathul Ulum Islamic Boarding School which was pioneered in 2015 and has only been officially registered based on a certificate from the Angkring Fathul Ulum Islamic Boarding School Foundation (officially recorded in the Notary Deed of Establishment No: 10 issued on 21 October 2019 and has been registered with the Ministry of Law. Islamic Boarding School is one of the potential institutions in Ngawonggo Village. Through its leader, Ustadz Habib, the Islamic Boarding School invites the surrounding community and students to build their village.

According to Toni (2016) states that Islamic boarding schools are classified into three dimensions. First, Islamic boarding school as a community education institution. Service and struggle are inherent in the socio-religious function. Second, Islamic boarding schools are centers of human resource development that emphasize the balance between the potential of the heart (taqwa-amaliya), fikru (scientific- intelligence) and jawarih (amliyah-skills) as three basic human potentials that should always be in balance. Third, the ability to maintain its extraordinary existence, from time to time has succeeded in contributing to its very significant role. According to the Ministry of Religion of the Republic of Indonesia (2003) stated that Islamic boarding schools develop their role from just religious and educational institutions to become community development institutions. At this level, Islamic boarding schools have functioned as centers of religion, education and community development (Center of Excellence).

\section{RELIGIOUS CENTER}

Islamic boarding schools prioritize religious education because religious education is a very important part of education with regard to aspects of attitudes and values. Religion regulates human relations with God, humans with humans, humans with nature and humans with themselves which can ensure harmony, balance, harmony in human life both as individuals and as members of society in achieving inner and outer happiness. According to Muchith (2003), religious education or religious education is one type of education that has a very important role in the context of the life of the nation and state. Religious education and religious education have the aim of developing the ability of students to understand, appreciate and practice religious values that harmonize their mastery in science, technology, and art. Religious education is education that teaches material according to religious adherents or beliefs. Thus, religious education can be said to be a learning process that has a goal or target of optimizing understanding and skills in the field of religious science, so that graduates really have a complete and comprehensive quality.

The Angkring Fathul Ulum Islamic Boarding School has a fairly large role for the community, one of which is increasing religious knowledge through regular recitation activities. This recitation activity not only serves to increase religious knowledge but also as a forum for friendship between fellow Muslims. Islamic religious education that has been given by Islamic boarding schools to students is expected to be used as a provision for life. They have a better understanding of religion than before. They can practice religious knowledge in people's lives, especially those in Ngawonggo Tajinan Village, Malang Regency. They can use the religious knowledge that has been given as a skill they have so that they can use these skills to preach or give lectures in public. And this means the efforts of Islamic boarding schools in printing output in accordance with what is expected.

The results of the research that become the output of the implementation of Islamic boarding school education are:

a) Santri have a better understanding of religion than before

b) Santri can practice religious knowledge in people's lives, especially those in Ngawonggo Tajinan Village, Malang Regency

c) They can use the religious knowledge that has been given as a skill they have so that they can use these skills to preach or lecture in public. 


\section{EDUCATION CENTER}

The development carried out and carried out by the Angkring Fathul Ulum Islamic boarding school in Ngawonggo Tajinan Village, Malang Regency does not change its main characteristics as an educational institution and center in a broad sense. These characteristics are stil needed by the surrounding community. Called in a broad sense because not all Islamic boarding schools organize madrasas, schools and courses like those held by other educational institutions. The regularity of education in Islamic boarding schools is formed because the recitation is according to the level of the book. The tiers are determined from generation to generation to form a curricular tradition that is seen in terms of content standards, the qualifications of the instructors and the graduate students. According to Alfiyani (2018), Islamic boarding schools are educational institutions outside of school that grow in the community. Islamic boarding school that are in the midst of society are not only educational institutions but also as religious and socio- religious broadcasting institutions. The location of the Islamic boarding school blends with the community and the students mingle with the surrounding community. This form is still found in various Islamic boarding school in rural areas. It is very natural that in the process of interaction synergy and harmony are created with one another. This method makes Islamic boarding school an inseparable part of the social structure of community.

The Angkring Fathul Ulum Islamic Boarding School as an educational center has a fairly high role, because as we all know the basis of the Islamic Boarding School is an educational institution, both formal (madsarah) and nonformal (skills provision). The Angkring Fathul Ulum Islamic Boarding School can be seen from several aspects, among others, in increasing the knowledge of students and the community towards new ideas. In this case, the Islamic boarding school can be said to be successful in carrying out its role because it is known that most of the people around the cottage are farming and some breeders and Islamic boarding schools want to cultivate and develop available forage and land so that people begin to know how to develop livestock, especially sheep and also the prospects to the future. According to Sulaiman et al. (2018) stated that traditional Islamic boarding schools as places of religious education have a clear social base because their existence is integrated with the community. Islamic boarding school generally live from, by, and for the community. Traditional Islamic boarding schools as Islamic institutions can be strengthened in academic and non-academic aspects but still maintain the value of strengthening religiosity and traditional Islamic boarding school while innovating to respond to changes in society. Changes in education in traditional Islamic boarding school that unite religiosity with social and economics in providing knowledge, skills, and independence to improve traditional Islamic boarding school and santri can empower the community.

According to Wahid in Halim (2017) Traditional Islamic boarding schools are one of the institutions in Indonesia that play an important role in improving education and morale in rural areas. Because traditional Islamic boarding school tend to reject centralization and because they are located in the middle of (rural) society, traditional Islamic boarding school can effectively play a role of empowerment and transformation.

\section{COMMUNITY DEVELOPMENT CENTER}

The Islamic boarding school is a religious educational institution as well as a social institution. On the one hand it must play an active role in guarding the moral journey of the community, but on the one hand it is also able to play an active role in responding to various kinds of community needs which have recently increased and varied.

Islamic boarding school should participate in overcoming community problems such as poverty, ignorance, environmental damage, limited resources, lack of environmental sanitation and others. So, it can be concluded that the development of a Islamic boarding school based community is an action taken by a boarding school in making people aware of the problems they are experiencing so that from the awareness process it can lead to an action to support the empowerment of the community towards social welfare. According to Yuliani (2010), community development as a process moves in stages from a certain condition or situation to the next stage, which includes progress and change in terms of specified criteria. Community development as a method is a way to achieve goals in such a way that some goals can be achieved. As a community development program, it is stated as a group of procedures and its contents are stated as a list of activities. The community development program as a movement is a struggle so that it becomes the reason for making people serve. Community development in this sense tends to institutionalize and build its own organizational structure, accept professional procedures and practitioners, thus the focus is on encouraging community development ideas.

The development of programs and activities for the Angkring Fathul Ulum Islamic Boarding School to act as the basis for regional development basically starts from the ability of the Islamic Boarding School to empower the potentials that exist in its environment by human resources in the Islamic Boarding School. Resources in Islamic boarding schools are given the ability, knowledge and skills in accordance with the demands of the community, so that they can act as a driving force for the community. According to Sunarto (2015) states that Islamic boarding schools and the community are two sides that cannot be separated, because they influence each other. Most Islamic boarding schools developed from the existence of community support, simply emerged and the establishment of Islamic boarding schools was an initiative of the community both individually and collectively. Likewise, social change in society is the dynamics of dynamic activities in Islamic boarding schools in education and society. Thus, the Islamic boarding school changed to appear as an educational institution engaged in education and social. Even further than that, Islamic boarding school has become a concept of social education for Muslim communities in cities and in rural areas.

\section{CONCLUSION}

The role of the Angkring Fathul Ulum Islamic boarding school as a center of excellence in the development of sheep farming, namely as an educational center, namely that students have a better understanding of religion than before, students can practice religious knowledge in people's lives, especially those in Ngawonggo Tajinan Village, Malang Regency educating to have good morals, religious centers such as increasing knowledge about religion, carrying out routine recitation activities, and community development centers, namely by an action taken by an Islamic boarding school in making people aware of the problems they are experiencing so that from the awareness process it can lead to a action to support the empowerment of the community towards social welfare. The sheep farming business which was initiated by the Islamic Boarding School as an influential institution is a strategic plan to develop the Ngawonggo village as a center for sheep farming. 


\section{REFERENCES}

[1] A. I. Sulaiman, Chusmeru, Masrukin, 2018. Strategy of Cooperative Islamic Boarding School as Economic Empowerment Community. INFERENSI,Jurnal Penelitian Sosial Keagamaan. Vol. 12, No.1, June 2018. Permalink/ DOI: http://dx.doi.org/10.18326/infsl3v12i1.25-44.

[2] Alfiyani, S. 2018. The Role of the Nurul Anwar Islamic Boarding School in the Development of the Religious Life of the Kembang Village Community, Dukuhseti District, Pati Regency [thesis]. Department of Sociology and Anthropology, Faculty of Social Sciences, Semarang State University.

[3] Azizah S., Irfan H. Djunaidi, Jaisy Aghniarahim Put Ritamara, and M. Agus Choiron. 2020. Evaluability Assessment of Traditional Islamic Boarding School's Sheep Farming Program in Crafts Villag e, Malang District, Indonesia. International Research Journal of Advanced Engineering and Science. Volume 5, Issue 4, pp. 147- 150 .

[4] Dewi, US, Muh. Hasan H and Anita F. 2014. Analysis of Sheep Fattening Business Income (Case Study at PT. Agro Jaya Mulya Subang). Vol. 1 (1): 1-18.

[5] Direktorat Jenderal Peternakan dan Kesehatan Hewan. Kementrian Pertanian, 2019. Livestock and Animal Health Statistick. http://ditjenpkh.pertanian.go.id
[6] Febrianno E. and U. MMP Siahaan. 2012. Investment Analysis on Goat and Sheep Fattening Project Based on The New Food Fermentation Farming Method (3f Method). The Indonesian Journal of Business Administration. Vol. 1, No. 9, 2012: 613-621.

[7] Ministry of Religion of the Republic of Indonesia. 2003. Islamic Boarding Schools and Madrasah Diniyah Growth and Development. Jakarta: Directorate General of Islamic Religious Institutions

[8] Muchith, M.S. 2003. Characteristics of Religious Education and Religious Education. Vol.1 (1): 1-15.

[9] Sunarto. 2015. The Role of Islamic Boarding Schools in the Development of the Islamic Culture of the Archipelago. Al- Tadzkiyyah: Journal of Islamic Education. Vol. 6(1): 34-46.

[10] Toni, H. 2016. Islamic Boarding Schools as Potential Development of Islamic Da'wah. Journal of Da'wah and Communication. Vol. 1(1): 97-110.

[11] Yuliani E. 2010. Development of Rural Community Based on Islamic Boarding Schools (Study at Miftahulhuda Al-Musri 'Islamic Boarding School, Ciranjang District, Cianjur Regency, West Java). IAIN Sultan Maulana Hasnuddin Banten.

[12] W. Halim, 2017. Role Traditional Islamic boarding school dalam Wacana dan Pemberdayaan Masyarakat Madani. AKADEMIKA, Vol. 22, No. 02 July-December 2017. Pp. 191-218. 